\title{
Assessment of Endothelium-derived Relaxing Factor from Human Coronary Arteries Using the Anti-platelet Aggregatory Effect
}

\author{
Takuji Kishimoto*1, Yoichiro Fukuzawa*1, Miyoko Abe*1, \\ Michio Hashimoto*2 and Manabu Tada*1 \\ ${ }^{* 1}$ Department of Environmental Medicine, Shimane Medical University, Izumo \\ *2 Department of Physiology, Shimane Medical University, Izumo
}

\section{Introduction}

Vascular endothelial cells can produce substances which modulate homeostatic interactions between platelets and the vessel wall. One of the most potent of these substances is prostacyclin, an antiplatelet cyclo-oxygenase product ${ }^{1}$. Prostacyclin inhibits platelet aggregation and induces vasodilatation by stimulating adenylate cyclase and inducing a rise in adenosine $3^{\prime}, 5^{\prime}$-cyclic monophosphate ${ }^{2}$.

Recently, the importance of endothelium-derived relaxing factor (EDRF) in the modulation of vascular smooth muscle cell reactivity has been established ${ }^{3)}$. The vascular relaxation induced by EDRF is mediated by the stimulation of soluble guanylate cyclase and the consequent rise in guanosine 3 ', 5 ' -cyclic monophosphate levels ${ }^{4}$. The essential identity of EDRF is still obscure, but its chemical character has been shown to be similar to that of nitric oxide ${ }^{5}$. Experimantal models for the indirect detection of the product of EDRF are complicated, requiring some method such as a cell culture system. EDRF has also been reported to inhibit platelet aggregation ${ }^{6}$. We consider that the response of washed platelets to thrombin in the presence of coronary artery provides an indirect measurement system for EDRF.

Many reports have suggested that dysfunction in the EDRF of endothelial cells plays a role in cardiovascular disease ${ }^{7 \sim 10}$ ). It is important to establish an experimental model for investigating the effect of environmental chemicals on the release or product of EDRF in the coronary artery, because certain environmental chemicals such as cadmium, lead and barium are suggested to be related to cardiovascular disease ${ }^{11 \sim 15)}$.

The present study was designed to assess whether endothelial cells of the human coronary artery can produce EDRF, like those of canine coronary artery, and to establish a simple new experimental model for investigating the effect of environmental chemicals on EDRF using human coronary arteries.

\section{Materials and Methods}

Platelet aggregation experiments were performed with both human and canine washed platelets ${ }^{6,16)}$.In brief, whole human or canine mixed blood (about $60 \mathrm{ml}$ ) with $10 \%(\mathrm{v} / \mathrm{v})$ of $3.8 \%$ trisodium citrate was centrifuged at $200 \times \mathrm{g}$ for 15 minutes to separate the platelet-rich plasma. The platelets were then isolated and washed with repeated centrifugation at $1,200 \times \mathrm{g}$ for 10 minutes in $0.38 \%$ citrate saline and $4.5 \mathrm{mM}$ disodium EDTA. The platelet count was adjusted to $1 \times 10^{8} / \mathrm{ml}$ with Krebs-Ringer bicarbonate solution (composition in $\mathrm{mM}: \mathrm{NaCl} 135, \mathrm{KCl} 5, \mathrm{NaHCO}_{3} 20$, glucose $10, \mathrm{CaCl}_{2} 2.5, \mathrm{MgSO}_{4} 0.7, \mathrm{KH}_{2} \mathrm{PO}_{4}$ 1.2, EDTA 0.026).

Isolated rings of coronary arteries with or without intact endothelium were obtained from either adult dogs weighing 25-30 kg or recipient hearts of cardiac transplant patients (AlabamaUniversity at Birmingham, USA) according to Ku's method ${ }^{17}$ ). Each coronary artery with an outside diameter of 1.0-1.5 mm was cut into rings 2-2.5 mm long. Disruption of the intimal endothelium was carried out by gentle rubbing of the intimal surface with a wooden applicator. For the indomethacin-pretreatment 
studies, coronary arteries were incubated with $1 \mu \mathrm{M}$ indomethacin for over 60 minutes with continuous oxygenation.

Platelet aggregation studies were carried out in the presence or absence of small rings of human or canine coronary arteries (with or without intact endothelium) and washed platelets in the Krebs-Ringer bicarbonate solution with constant stirring, by using a BIO/DATA PAP-2A aggregometer (Worcester, USA). Platelet aggregation was assessed by measurement of the slope-rate as in the method of Furlong ${ }^{18}$.

\section{Results}

\section{Canine coronary artery experiment:}

As shown in Fig. 1, the addition of small rings of canine coronary artery with intact endothelial cells, but not of those with disrupted endothelial cells, inhibited thrombin $(0.025 \mathrm{unit} / \mathrm{ml})$-induced platelet aggregation. The anti-platelet aggregatory ef fect of rings with intact endothelial cells was reduced by pretreatment with indomethacin, a blocker of the cyclo-oxygenase pathway.

Figure 2 illustrates the effects of small rings of canine coronary arteries pretreated with acetylcholine or superoxide dismutase on thrombin-induced platelet aggregation in the presence of indomethacin. Pretreatment of canine coronary arteries with acetylcholine, a stimulator of the release or product of EDRF, or superoxide dismutase, which prolongs the half-life of EDRF, increased the anti-platelet aggregatory effect compared with indomethacin alone. In similar experiments done using small rings without intact endothelium (data not shown), these agents had no effect, indicating that the anti-platelet aggregatory effect was endothelium-dependent.

As the anti-platelet aggregatory effect was not observed with hemoglobin, an inhibitor of the release or product of EDRF (Fig. 3), this experiment supports the conclusion that the anti-platelet aggregatory effect is dependent on EDRF.
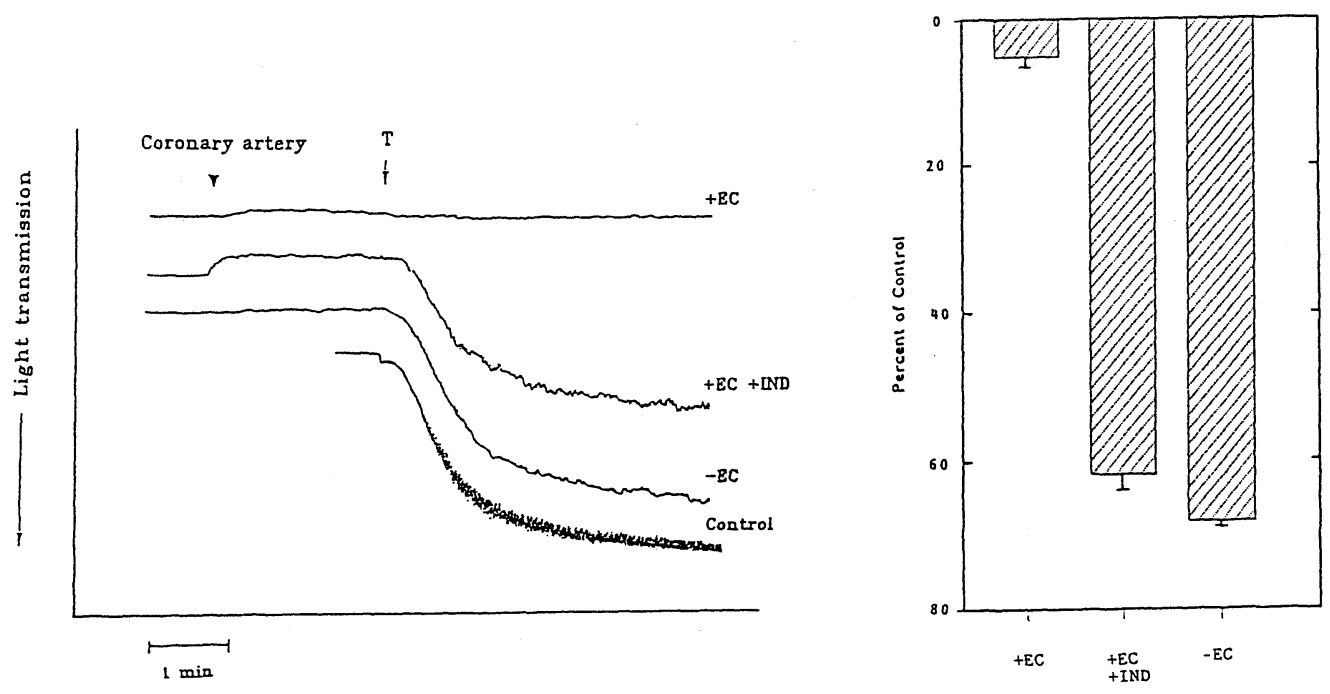

Fig. 1 Effects of addition of small segments of canine coronary artery on thrombin-induced aggregation of washed canine platelets.

Left panel: an example of these experiments. $\mathrm{T}: 0.025 \mathrm{unit} / \mathrm{ml}$ thrombin, $+\mathrm{EC}$ : endothelium -intact canine coronary artery, - EC: endothelium-disrupted coronary artery, + IND: $1 \mu \mathrm{M}$ indomethacin. Right panel: mean percent of the control for the slope rate of the aggregating curve. Vertical bars: standard deviations of the mean, sample size: + EC $(n=35),+E C+\operatorname{IND}(n=28),-\operatorname{EC}(n=28)$. 

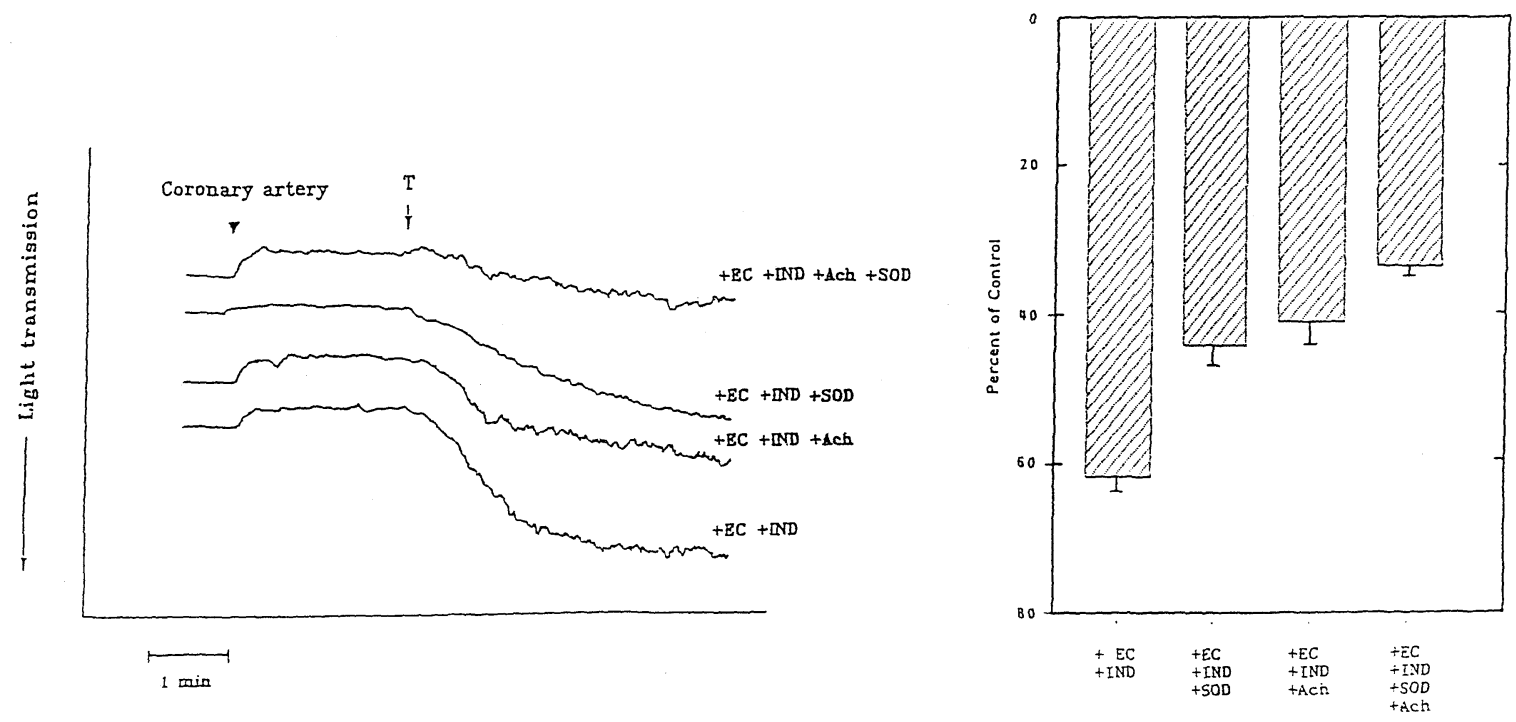

Fig. 2 Effects of acetylcholine and superoxide dismutase on canine coronary endothelialdependent inhibition of thrombin-induced aggregation of washed canine platelets. Left panel: an example of these experiments. T: $0.025 \mathrm{unit} / \mathrm{ml}$ thrombin, $+\mathrm{EC}$ : endothelium - intact canine coronary artery, + IND: $1 \mu \mathrm{M}$ indomethacin, + Ach : $1 \mu \mathrm{M}$ acetylcholine, +SOD: 40 unit/ml superoxide dismutase. Right panel : mean percent of the control for the slope rate of the aggregating curve. Vertical bars: standard deviations of the mean, sample size: $+\mathrm{EC}+\mathrm{IND}(\mathrm{n}=28),+\mathrm{EC}+\mathrm{IND}+\mathrm{SOD}(\mathrm{n}=12),+\mathrm{EC}+\mathrm{IND}+\mathrm{Ach}$ $(n=17),+E C+I N D+S O D+A c h(n=14)$.
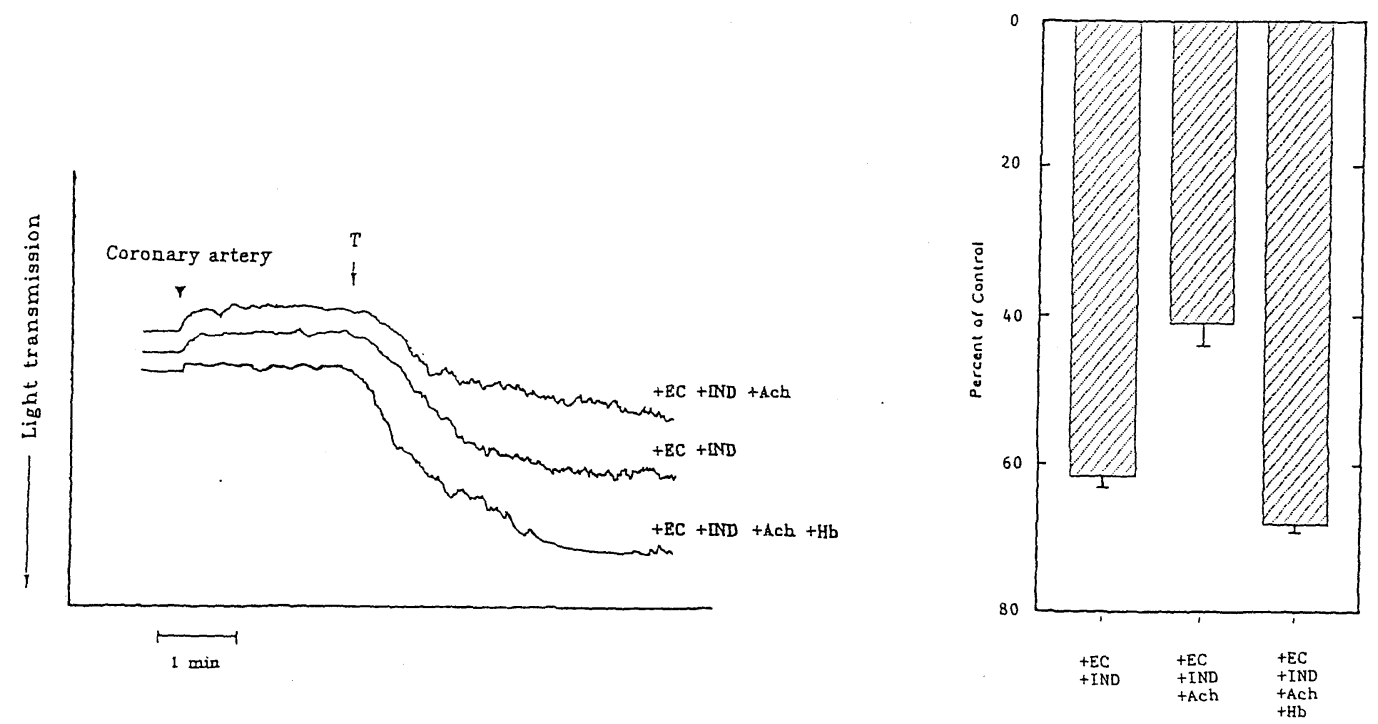

Fig. 3 Effects of hemoglobin on canine coronary endothelial-dependent inhibition of thrombin-induced aggregation of washed canine platelets.

Left panel: an example of these experiments. $\mathrm{T}: 0.025 \mathrm{unit} / \mathrm{ml}$ thrombin, $+\mathrm{EC}$ : endothelium-intact canine coronary artery, + IND: $1 \mu \mathrm{M}$ indomethacin, $+\mathrm{Ach}: 1 \mu \mathrm{M}$ acetylcholine, $+\mathrm{Hb}: 10 \mu \mathrm{M}$ hemoglobin. Right panel: mean percent of the control for the slope rate of the aggregating curve. Vertical bars: standard deviations of the mean, sample size: $+\mathrm{EC}+\operatorname{IND}(n=28),+\mathrm{EC}+\mathrm{IND}+\mathrm{Ach}(\mathrm{n}=17),+\mathrm{EC}+\mathrm{IND}+\mathrm{Ach}+\mathrm{Hb}(\mathrm{n}=11)$. 


\section{Human coronary artery experiment:}

Figure 4 shows the effect of the addition of small rings of human coronary artery with or without endothelial cells on thrombin $(0.025 \mathrm{unit} / \mathrm{ml})$-induced platelet aggregation. Small rings of human coronary artery with intact endothelial cells, but not those with disrupted endothelial cells, inhibited thrombin-induced platelet aggregation .

As illustrated in Fig. 5, pretreatment with indomethacin reduced the anti-platelet aggregatory effect of the addition of small rings with intact endothelial cells. Histamine, a stimulator of the release or product of EDRF, and superoxide dismutase increased the anti-platelet aggregatory effect of small rings pretreated with indomethacin. Hemoglobin, an EDRF inhibitor, blocked the increased anti-platelet aggregation caused by histamine. Figure 6 presents a summary of the human coronary artery experiments.

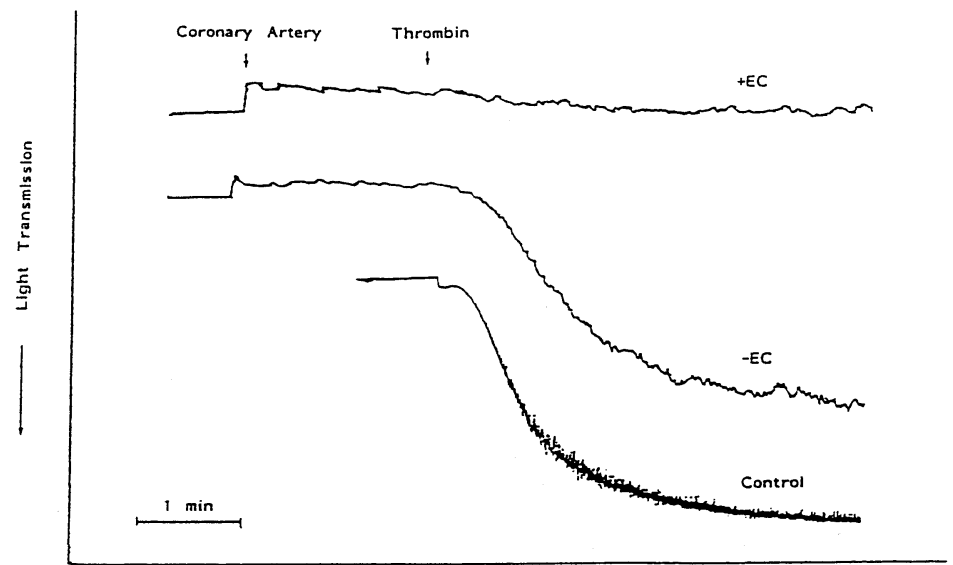

Fig. 4 Effects of addition of small segments of human coronary artery on thrombin-induced aggregation of washed human platelets.

Thrombin: 0.025 unit/ml thrombin, +EC: endothelium-intact human coronary artery, -EC: endothelium-disrupted human coronary artery .

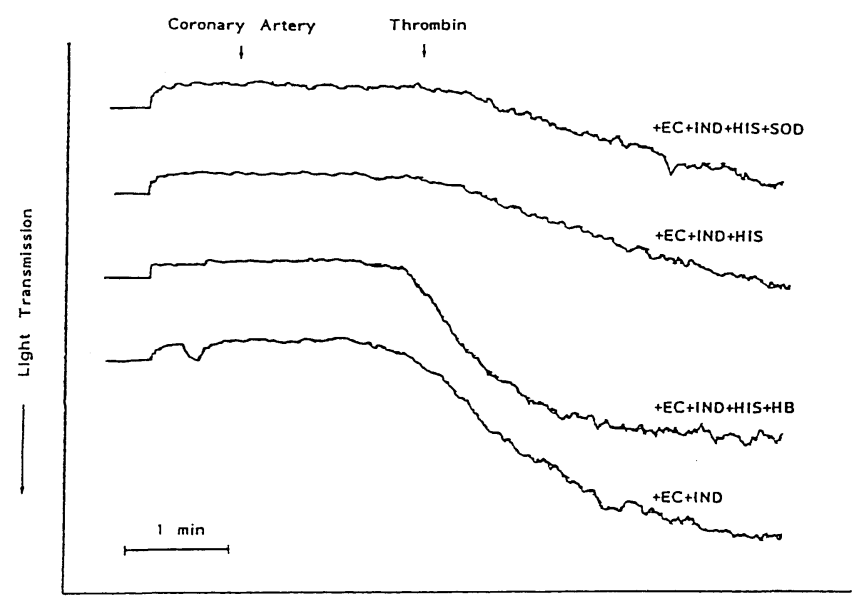

Fig. 5 Effects of indomethacin, histamine, superoxide dismutase and hemoglobin on human coronary endothelial-dependent inhibition of thrombin-induced aggregation of washed human platelets.

Thrombin: $0.025 \mathrm{unit} / \mathrm{ml}$ thrombin, + EC: endothelium-intact human coronary artery, + IND: $1 \mu \mathrm{M}$ indomethacin, + HIS: $1 \mu \mathrm{M}$ histamine, + SOD: $40 \mathrm{unit} / \mathrm{ml}$ superoxide dismutase, $+\mathrm{HB}: 10 \mu \mathrm{M}$ hemoglobin . 


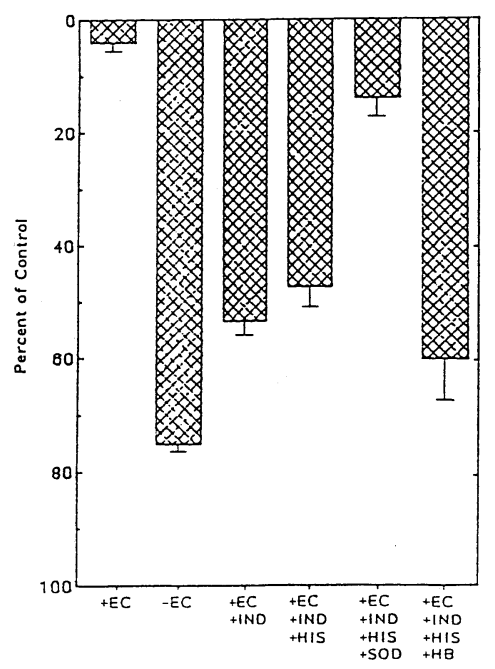

Fig. 6 Effects of indomethacin, histamine, superoxide dismutase and hemoglobin on human coronary endothelial-dependent inhibition of thrombin-induced aggregation of washed human platelets.

Mean percent of the control for the slope rate of the aggregating curve. Vertical bars: standard deviations of the mean.

+EC: endothelium-intact human coronary artery,-EC: endothelium-disrupted human coronary artery, + IND: $1 \mu \mathrm{M}$ indomethacin, + HIS: $1 \mu \mathrm{M}$ histamine, + SOD: $40 \mathrm{unit} / \mathrm{ml}$ superoxide dismutase, $+\mathrm{HB}: 10 \mu \mathrm{M}$ hemoglobin. Sample size: $+\mathrm{EC}(\mathrm{n}=6),-\mathrm{EC}$ $(n=7),+E C+\operatorname{IND}(n=4),+E C+\operatorname{IND}+\mathrm{His}(n=5),+\mathrm{EC}+\mathrm{IND}+\mathrm{HI}+\mathrm{SOD}(\mathrm{n}=4),+\mathrm{EC}+$ $\mathrm{IND}+\mathrm{His}+\mathrm{Hb}(\mathrm{n}=5)$.

\section{Discussion}

The addition of small segments of canine coronary artery with intact endothelial cells completely inhibited thrombin-induced platelet aggregation. This may be mainly due to prostacyclin, because the anti-platelet aggregatory effect was greatly reduced by indomethacin, a blocker of the cyclo-oxygenase pathway. The anti-platelet aggregatory effect in canine coronary artery with intact endothelium pretreated by indomethacin was slightly greater than that in canine coronary artery with disrupted endothelium . It has been reported that endothelial cells can produce some substances which have an anti-platelet aggregatory effect, such as prostacyclin, prostaglandin $\mathrm{D}_{2}$, endothelins and EDRF 1 6, 19 21). Thiemermann, et al. ${ }^{20}$ ) and Lidbury, et al. ${ }^{21)}$ demonstrated that endothelins (endothelin-1, and 3 ) do not affect platelet aggregation in vitro, but substantially inhibit platelet aggregation in the anaesthetized rabbit, as measured ex vivo, and that this effect was mediated by the release of anti-aggregatory cyclo-oxygenase products, most likely prostacyclin, into the circulation. The production of prostacyclin and prostaglandin $\mathrm{D}_{2}$, antiplatelet cyclo-oxygenase products, and the effect of endothelins can be blocked by the cyclo-oxygenase inhibitor indomethacin. Thus, it seems that the anti-platelet aggregatory effect in canine coronary artery pretreated with indomethacin depended mainly on EDRF. Furthermore, the effect was enhanced by acetylcholine and superoxide dismutase, a stimulator of EDRF product and a substance prolonging the half-life of EDRF, respectively ${ }^{3,22}$. In addition, the enhanced anti-platelet aggregatory effect of indomethacin-pretreated canine coronary artery induced by acetylcholine was blocked by hemoglobin, an inhibitor of $\mathrm{EDRF}^{23}$ ).

In the human coronary artery experiments, the anti-platelet aggregatory effect in human coronary artery pretreated with indomethacin was similar to that in canine coronary artery. That is, the anti-platelet aggregatory effect was enhanced by histamine and superoxide dismutase, stimulators of the function of EDRF, and blocked by hemoglobin. Thus, human coronary artery can produce EDRF, 
which inhibits platelet aggregation, in addition to inducing vasodilatation ${ }^{3,4)}$.

This experimental system using small segments of vessel in an aggregometer is simpler than previous experimental models such as those using cultured cells. Experiments with EDRF using cultured human vascular endothelial cells need much effort, such as the technique of primary culture, determination of the typical characteristics, checking the normality, the maintenance (continuous subculture) of cells and consideration of aging ${ }^{24,25)}$. This experimental system can be used to study EDRF with many kinds of human vessels.

Dysfunction of EDRF has been suggested to play a role in cardiovascular disease ${ }^{7 \sim 10)}$. It is important to determine the relationship between environmental chemicals such as cadmium and lead, and cardiovascular disease ${ }^{11 \sim 15)}$. This model is useful for the study of interactions between the function of EDRF in human coronary artery and environmental chemicals. An experiment on the effect of trace elements of EDRF in human arteries is in progress using this method.

In conclusion, the results of the present study suggest that endothelial cells of the human coronary artery produce EDRF, which has an anti-platelet aggregatory effect, in addition to its vasodilation properties. This experimental system is useful to examine the effects of environmental chemicals on EDRF in the human coronary artery .

\section{Summary}

Responses of human and canine washed platelets to thrombin in the presence and absence of human and canine coronary arteries were examined to establish a simple indirect measurement system for endothelium-derived relaxing factor (EDRF). Isolated rings of coronary arteries were obtained from either adult dogs or recipient hearts of cardiac transplant patients. The addition of small segments of canine and human coronary arteries with intact endothelia inhibited thrombin-induced platelet aggregation, but those with disrupted endothelia did not. Pretreatment of human and canine coronary arteries with the cyclo-oxygenase inhibitor indomethacin markedly attenuated the observed effect. The anti-platelet aggregatory effect of indomethacin-pretreated coronary artery was enhanced by acetylcholine or histamine, stimulators of EDRF production, or superoxide dismutase, which prolongs the half-life of EDRF, and inhibited by the EDRF inhibitor hemoglobin. These results suggest that endothelial cells of the human coronary artery, like the canine coronary artery, can produce EDRF which inhibits platelet aggregation, and that this simple experimental model is useful to examine the effect of environmental chemicals on EDRF in the human coronary artery .

\section{Acknowledgements}

We thank Dr. David D. Ku, Department of Pharmacology, University of Alabama at Birmingham, for his continuous support of our research and for his expert advice.

\section{References}

1 ) Moncada, S., Gryglewski, R., Bunting, S. and Vane, J.R.: An enzyme isolated from arteries transforms prostaglandin endoperoxides to an unstable substance that inhibits platelet aggregation, Nature, 263, 663-665 (1976).

2 ) Tateson, J.E., Moncada, S. and Vane, J.R.: Effects of prostacyclin (PGX) on cyclic AMP concentrations in human platelets, Prostaglandins, 13, 389-397 (1977).

3 ) Furchgott, R.F. and Zawadzki, J.V.: The obligatory role of endothelial cells in the relaxation of arterial smooth muscle by acetylcholine, Nature, 288, 373-376 (1980).

4 ) Rapoport, R.M., Draznin, M.B. and Murad, F.: Endothelium-dependent relaxation in rat aorta may be mediated through cyclic GMP-dependent protein phosphorylation, Nature, 306, 174-176 (1983).

5 ) Ignarro, J.L.: Biological actions and properties of endothelium-derived nitric oxide formed and released from artery and vein, Circ. Res., 65, 1-21 (1989).

6 ) Azuma, H. , Ishikawa, M. and Sekizaki, S.: Endothelium-dependent inhibition of platelet 
aggregation, Br. J. Pharmacol., 88, 411-415 (1986).

7 ) Luscher, T.F. and Vanhoutte, P.M.: Endothelium-dependent contractions to acetylcholine in the aorta of the spontaneously hypertensive rat, Hypertension, 8, 344-348 (1986) .

8 ) Luscher, T.F., Raji, L. and Vanhoutte, P.M.: Endothelium-dependent vascular responses in normotensive and hypertensive Dahl rats, Hypertension, 9, 157-163 (1987).

9 ) Luscher, T.F., Diederich, D., Weber, E., Vanhoutte, P.M. and Buhler, F.R.: Endotheliumdependent responses in carotid and renal arteries of normotensive and hypertensive rats, Hypertension, 11, 573-578 (1988).

10) Sugimoto, T., Tobian, L. and Ganguli, M.C.: High potassium diets protect against dysfunciton of endothelial cells in stroke-prone spontaneously hypertensive rats, Hypertension, 11, 579-585 (1988).

11) Webb, R.C., Winquist, R.J., Victery, W. and Vander, A.J. : In vivo and in vitro effects of lead on vascular reactivity in rats, Am. J. Physiol. , 241, (Heart Circ. Physiol. 10), H211-H216 (1981) .

12) Guy, H., Claude, B. and Michael, A. I. : Cadmium and lead content of maternal and newborn hair: relationship to parity, birth weight, and hypertension, Arch. Environ. Health, 36, 221-227 (1981).

13) Brenniman, G.R., Kojola, W.H., Levy, P.S., Carnow, B.W. and Namekata, T. : High barium levels in public drinking water and its association with elevated blood pressure, Arch. Environ. Health, 36, 28-32 (1981).

14) Voors, A.W., Johnson, W.D. and Shuman, M.S. : Additive statistical effects of cadmium and lead on heart-related disease in a North Carolina autopsy series, Arch. Environ. Health, 37, 98-102 (1982).

15) Carmignani, M., Boscolo, P. and Preziosi, P.: Cardiovascular actions of lead in rats as related to the level of chronic exposure, Arch. Toxicol., Suppl. 12, 326-329 (1988).

16) Alheid, U., Frolich, C. and Forstermann, U.: Endothelium-derived relaxing factor from cultured human endothelial cells inhibits aggregation of human platelets, Thromb. Res. , 47, 561-571 (1987) .

17) Ku, D.D.: Mechanism of thrombin-induced endothelium-dependent coronary vasodilation in dogs: role of its proteolytic enzymatic activity, J. Cardiovasc. Pharmacol. , 8, 29-36 (1986).

18) Furlong, B., Henderson, A.H., Lewis, M.J. and Smith, J.A.: Endothelium-derived relaxing factor inhibits in vitro platelet aggregation, Br. J. Pharmacol., 90, 687-692 (1987).

19) Yanagisawa, M.H., Kurihara, S., Kimura Y., Tomobe, M., Kobayashi, Y., Mitsui, Y., Yazaki, K., Goto, K. and Masaki, T. : A novel potent vasoconstrictor peptide produced by vascular endothelial cells, Nature, 332, 411-414 (1988).

20) Thiemermann, C., Lidbury, P.S., Thomas, G.R. and Vane, J.R.: Endothelin-1 releases prostacyclin and inhibits ex vivo platelet aggregation in the anesthetized rabbit, J. Cardiovasc. Pharmacol. , 13, (Suppl. 5), S138-S141 (1989).

21) Lidbury, P.S., Thiemermann, C., Thomas, G.R. and Vane, J.R.: Endothelin-3: selectivity as an anti-aggregatory peptide in vivo, Eur. J. Pharmacol., 166, 335-338 (1989).

22) Lugnier, C., Schoeffter, P., Lebec, A., Strouthou, E. and Stoclet, J.C.: Selective inhibition of cyclic nucleotide phosphodiesterases of human, bovine and rat aorta, Biochem. Pharmacol. , 35, 1743-1751 (1986).

23) Martin, W., Villani, G.M., Jothianandan, D. and Furchgott, R.F.: Selective blockade of endothelium-dependent and glyceryltrinitrate-induced relaxation by hemoglobin and methylene blue in rabbit aorta, J. Pharmacol. Exp. Ther., 232, 708-716 (1985).

24) Kishimoto, T., Fukuzawa, Y. and Tada, M.: Studies on human vascular endothelial cells, 1. Basic attempt to primary cell culture, Bull. Shimane Med. Univ. , 5, 23-28 (1982). (in Japanese with English abstract)

25) Kishimoto, T.: The effects of antifebriles on human vascular endothelial cells at high temperature in cell culture, Jpn. J. Biometeor., 24, 117-124 (1987). (in Japanese with English abstract) 


\title{
抗血小板凝集効果を用いた ヒト冠動脈の内皮細胞由来弛緩因子の測定
}

\author{
岸 本 拓 治*1, 福 沢 陽一郎*1, 阿 部 美代子*1, \\ 橋 本 道 男*2, 多田學*1 \\ *1 島根医科大学環境保健医学教室, $* 2$ 島根医科大学生理学教室
}

\begin{abstract}
内皮細胞由来弛緩因子 $(\mathrm{EDRF})$ に関する簡便な間接的測定方法を確立するために，ヒトおよび犬の冠動脈を用いて， トロンビンに対するヒトおよび犬の血小板の反応性を観察した。冠動脈の分離リングは犬と心臓移植患者から入手した。 正常な内皮細胞を有する犬およびヒトの冠動脈を添加することにより，トロンビンにより引き起こされる血小板凝集を 阻害したが, 内皮細胞を剥離した冠動脈では, 血小板凝集は阻害されなかった。サイクロオキシゲナーゼ阻害剤のイン ドメサシンで前処理した冠動脈では血小板凝集阻害作用が明らかに低下した。インドメサシンで前処理した冠動脈の抗 血小板凝集作用は, EDRF産生の刺激剂であるアセチルコリンやヒスタミンにより，またEDRFの半減期の延長するスー パーオキシドディスムターゼにより増強したが，EDRFの阻害剤であるへモグロビンにより抗血小板凝集作用は阻害さ れた。これらの結果は, ヒト冠動脈の内皮細胞が犬冠動脈と同様にEDRFを産生し血小板凝集を阻害すること, なたこ の簡便な実験モデルは環境中の諸化学物質のヒト冠動脈由来EDRFへの影響を検討するために有効であることを示唆し ている。
\end{abstract}

Key words : Endothelium-derived relaxing factor, Human coronary artery, Platelet aggregation 内皮細胞由来弛緩因子，ヒ卜冠動脈，血小板凝集 